Krivokapić, S., Pejatović, T. (2021): Effect of the vegetation cycle on total phenolic and flavonoid compounds in Hypericum perforatum L. and Melissa officinalis L. collected in Montenegro. Agriculture and Forestry, 67 (1): 181-190

DOI: 10.17707/AgricultForest.67.1.15

KRIVOKAPIĆ SLA円ANA ${ }^{1}$, PEJATOVIĆ TIJANA ${ }^{I}$

\title{
EFFECT OF THE VEGETATION CYCLE ON TOTAL PHENOLIC AND FLAVONOID COMPOUNDS IN Hypericum perforatum $L$. AND Melissa officinalis L. COLLECTED IN MONTENEGRO
}

\begin{abstract}
SUMMARY
Effect of vegetation cycle on total phenolic content (TPC) and total flavonoid content (TFC) in $80 \%$ methanolic and $50 \%$ ethanoic extracts in wild growing Hypericum perforatum L. and Melissa officinalis L. from different habitats in Montenegro was analyzed.

It was found that the type of extraction solvent and the altitude of selected habitats affect the value of the detected TPC and TFC. The highest TPC and TFC values were found in $80 \%$ methanolic extract of $\mathrm{H} 1$ locality in the month of July (16.66 mgGAE/gDW and $6.91 \mathrm{mgQE} / \mathrm{gDW}$ ) as well as of M1 locality in the month of August (41.66 mgGAE/gDW and $11.07 \mathrm{mgQE} / \mathrm{gDW}$ ) while 50\% ethanolic extracts showed lower TPC and TFC content.

The TPC and TFC values of $H$. perforatum L. extracts were found to be highly variable in quantity and their dynamics was found irregular, while for the M. officinalis L. extracts the TPC and TFC were found to change in quantity in a regular manner during the plants vegetation cycle with the peak in the flowering stage (August), while the lowest concentration of these bioactive substances was found during fruiting stage (September) which is of the great value for the harvesting time recommendation.
\end{abstract}

Keywords: total phenolic content, total flavonoids content, Hypericum L., Melissa L.

\section{INTRODUCTION}

Plants are producing a multitude of bioactive compounds (Dixon, 2001), among them polyphenols like phenolics and flavonoids, that have been a limitless source of experimental analysis (Sujana et al., 2013) and which also have numerous different functions (Halliwell 2006, Albayrak et al., 2010, Sarbu et al., 2019, Obložinský et al., 2006). Phenolics possess antioxidant, antiproliferative, anticancer and anti-inflammatory activities, as well as antibacterial, antiviral and

\footnotetext{
${ }^{1}$ Slađana Krivokapić (corresponding author: sladjana.krivokapic@gmail.com), Tijana Pejatović, University of Montenegro, Faculty of Natural Sciences and Mathematics, MONTENEGRO

Notes: The authors declare that they have no conflicts of interest. Authorship Form signed online. 
antifungal potential (Halliwell, 2006), while flavonoids are considered to have antithrombotic, antineoplastic and anti-hypertensive activities (Benayad et al., 2014, Sarbu et al., 2019) as well as antilipoxygenase activity (Obložinský et al., 2006) among the others.

Phenolics and flavonoids, which are responsible for the biological activities of Hypericum perforatum L., can often be found in the leaves and flowers of a plant (Zobayed et al., 2006) and the disposal model of some flavonoids in plants reproductive complex during the flowering stage was also studied in a related Hypericum species (Mártonfi, 2006). H. perforatum L. is well recognized when it comes to flavonoids content (quercetin and kaempferol at the first place) (Nahrstedt and Butterweck, 2010) which are found in its leaves as glycosides located in special compartments of the cells of epidermis, and which are responsible for UV-protection (Germ, et al., 2010).

Leaves from Melissa officinalis L. contain flavonoids (quercitrin, rhamnocitrin, luteolin), as well as polyphenolics (rosmarinic acid, caffeic acid and protocatechuic acid) (Sofowora, et al., 2013). The biological action of its extracts is primarily connected, similar to other plants, to the phenolics, flavonoids and terpenoids content (Škrovánková, et al., 2012).

In the literature there are several studies about phytochemical content, antimicrobial, antimutagenic and cytotoxic activity of essential oils from plants growing in Montenegro (Šćepanović et al., 2019, Damjanović-Vratnica et al., 2015, Bošković, et al., 2018, Božović et al., 2015, 2018; Artini et la., 2018, Tadić et al., 2017, Stešević et al., 2016, Vuković-Gačić et al., 2006), while the effect of vegetation cycle on chemical content and antibacterial activity of essential oil was investigated by Damjanović-Vratnica et al., (2011) for the Satureja montana L. species.

The main goal of this study is to present dynamics of total phenolic and total flavonoids content during vegetation cycle in two different plant species $H$. perforatum L. and M. officinalis L. wild-growing in Montenegro.

\section{Plant material}

\section{MATERIAL AND METHODS}

Wild-growing plants of $H$. perforatum L. and M. officinalis L. were collected in Montenegro in localities H1 (Ljubišnja), H2 (Vijenac) (Table 1.a) and M1 (Zenica), M2 (Stari Bar) (Table 1.b) respectively. The plant material was collected by hand from July to September 2014. The plant material was determined in the laboratory of the Study program for Biology, Faculty of Natural Sciences and Mathematics, University of Montenegro, and genus and species of the plant were identified and confirmed.

\section{a)Aparatus}

For the purpose of extraction water bath from the manufacturer Vims elektrik was used, and after the extraction, sand bath and automated rotor-vacuum evaporator IKA rv 10 were used for removing dissolvent from the extract. 
Table 1. Localities description for H. perforatum L. (a) and M. officinalis L. (b).

a.

\begin{tabular}{cccc}
\hline No. & Locality & Coordinates & Altitude \\
\hline 1. & Ljubišnja / H1 & $43^{\circ} 17^{\prime} 48^{\prime} \mathrm{N} 19^{\circ} 0558^{\prime \prime} \mathrm{E}$ & $1509 \mathrm{~m}$ \\
2. & Vijenac / H2 & $43^{\circ} 21^{\circ} 03^{\prime} \mathrm{N} 19^{\circ} 2721^{\prime \prime} \mathrm{E}$ & $1373 \mathrm{~m}$ \\
\hline
\end{tabular}

b.

\begin{tabular}{cccc}
\hline No. & Locality & Coordinates & Altitude \\
\hline 1. & Zenica / M1 & $43^{\circ} 17^{\prime} 29^{\prime} \mathrm{N} 19^{\circ} 21^{\prime} 03^{\prime \prime} \mathrm{E}$ & $846 \mathrm{~m}$ \\
2. & Stari Bar / M2 & $42^{\circ} 05^{\prime} 46^{\prime} \mathrm{N} 19^{\circ} 0809^{\prime \prime} \mathrm{E}$ & $178 \mathrm{~m}$ \\
\hline
\end{tabular}

All measurements were performed on a UV-VIS spectrophotometer CECIL CE 2021 in quartz cuvettes which were $10 \mathrm{~mm}$ wide and with $83 \%$ light transmitting ability at $200 \mathrm{~nm}$.

\section{b)Chemicals and reagents}

Folin-Ciocalteu reagent was obtained from a producor named ALDRICH Chemistry. Solutions of 7,5\% $\mathrm{NaHCO}_{3}, \quad 2,5 \% \quad \mathrm{AlCl}_{3} \mathrm{xH}_{2} \mathrm{O}$, and $10 \%$ $\left(\mathrm{Na}\left(\mathrm{CH}_{3} \mathrm{COO}\right) * 3 \mathrm{H}_{2} \mathrm{O}\right)$ were freshly prepared. Gallic acid and quercetin were used as reference substances.

\section{Preparation of extracts}

Hydroalcoholic extraction was done according to a modified method of Fialová et al., (2008). Namely, to the $0.10 \mathrm{~g}$ of powdered drug (dried herba of $H$. pefroratum $L$. or dried folium of M. officinalis L.) $15 \mathrm{ml}$ of a) $50 \%$ ethanol and b) $80 \%$ methanol was added in a glass flask, and it was left to boil in a water bath for $30 \mathrm{~min}$. Filtrate was poured into a measuring flask where the dilution was done. For the purpose of total phenolics determination filtrate was diluted 5 times, and for the purpose of total flavonoids determination, it was diluted 10 times.

\section{Total phenolic content (TPC)}

The TPC were determined according to the Habila et al., (2010) by using Folin-Ciocalteau assay. Namely, in $1.5 \mathrm{ml}$ of Folin-Ciocalteau working solution was added $1.5 \mathrm{ml}$ of $\mathrm{NaHCO}_{3}$ and $200 \mu \mathrm{l}$ of examinating samples. The samples were incubated at room temperature for $30 \mathrm{~min}$. Then, absorbance was measured spectrophotometrically at $765 \mathrm{~nm}$. The results for TPC concentration were expressed as milligrams of gallic acid equivalents per gram of dry weight (mgGAE/gDW). All the analyses were repeated 6 times.

\section{Total flavonoids content (TFC)}

The TFC were determined spectrophotometrically by $\mathrm{AlCl}_{3}$ method, according to modified assay described in Zou, et al., (2004). $1 \mathrm{ml} 2.5 \%$ $\mathrm{AlCl}_{3} \times 6 \mathrm{H}_{2} \mathrm{O}$ was mixed with $1 \mathrm{ml}$ of $\mathrm{NaOH}$ and left for the reaction for $5 \mathrm{~min}$. Following this, $2 \mathrm{ml}$ of $10 \%\left(\mathrm{Na}\left(\mathrm{CH}_{3} \mathrm{COO}\right) * 3 \mathrm{H}_{2} \mathrm{O}\right)$ and $6 \mathrm{ml}$ of $70 \%$ ethanol and $1 \mathrm{ml}$ of examinating sample were added. After the incubation of $30 \mathrm{~min}$ on the room temperature, the absorbance was measured at $420 \mathrm{~nm}$. TFC was expressed 
as mg quercetin per gram of dry weight (mgQE/gDW). All the analyses were repeated 6 times.

\section{RESULTS AND DISCUSSION}

Phenolics and flavonoids are bearers of plants biological activities (Olech, et al., 2012, Božin, et al., 2013). In this paper the variation in TPC and TFC of the wild-growing $H$. perforatum L. and $M$. officinalis L. from several different localities and different habitats in Montenegro, during their phenological cycle was investigated.

During the observation and analyses of TPC and TFC, in the dried herb (herbae) of wild-growing $H$. perforatum L., which were obtained during three consecutive months (July, August, September) for 80\% methanolic and 50\% ethanolic extracts (Figure 1. and 2.), a stable regularity in the dynamics of these bioactive substances during the vegetation period was not found.

In terms of $80 \%$ methanolic extracts (Figure1.a) the peak of TPC was found in July (16.66 mgGAE/gDW - for the H1 locality), while $50 \%$ ethanolic extract showed the peak of TPC in September $(13.5 \mathrm{mgGAE} / \mathrm{gDW}$ - for the H1 locality) (Figure 1.b).

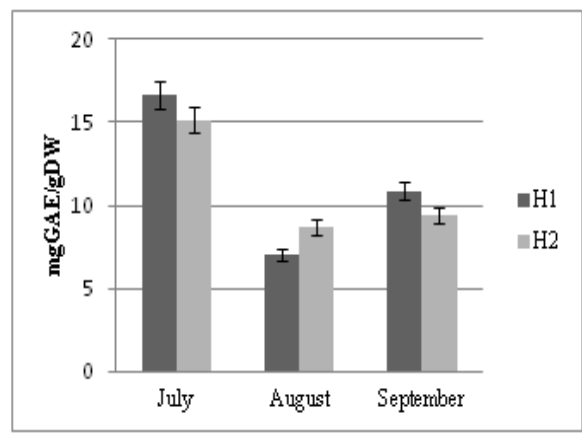

a)

b)

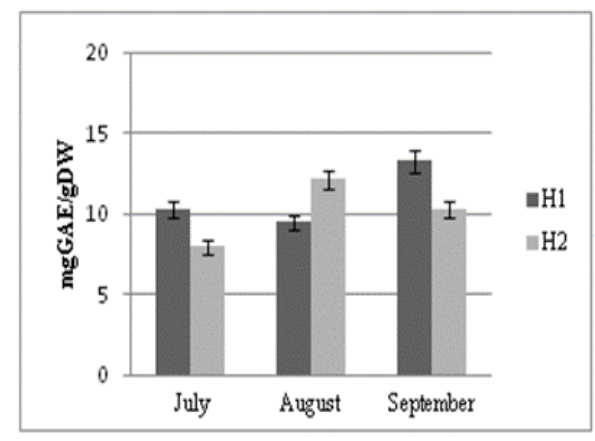

Figure 1.a) Dynamics of total phenolic content in $80 \%$ methanolic hydroalcoholic extract of the wild-growing $H$. perforatum L. herba from the locality of H1 (Ljubišnja) i H2 (Vijenac). b)Dynamics of total phenolic content in $50 \%$ ethanolic hydroalcoholic extract of the wild-growing $H$. perforatum $\mathrm{L}$. herba from the locality of H1 (Ljubišnja) i H2 (Vijenac).

When it comes to TFC in $80 \%$ methanolic extracts of $H$. perforatum $\mathrm{L}$. (Figure 2.a) their peak was found in July (6.91 mgQE/gDW - for the H1 locality) and the 50\% ethanolic (Figure 2.b) extract also showed the peak of TFC in July (4.54 mgQE/gDW - for the H1 locality).

Present data for TPC values were lower than in Sarikurkcu et al., (2020) and it seems that this is the case due to the different extraction type. This 
investigation also showed significantly lower TPC and TFC data than Tausevski et al., (2019) found in flowering stage samples collected in Northern Macedonia.

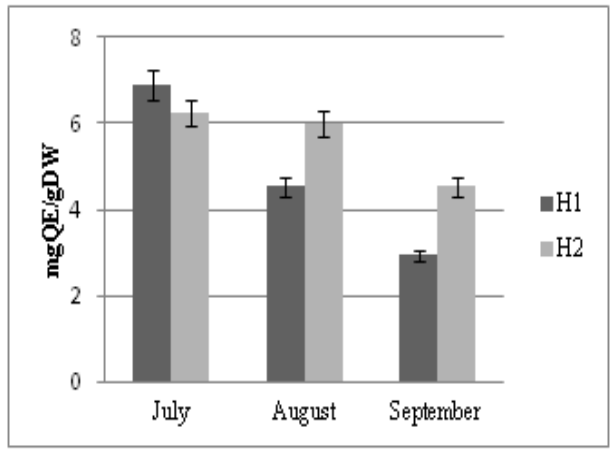

a)

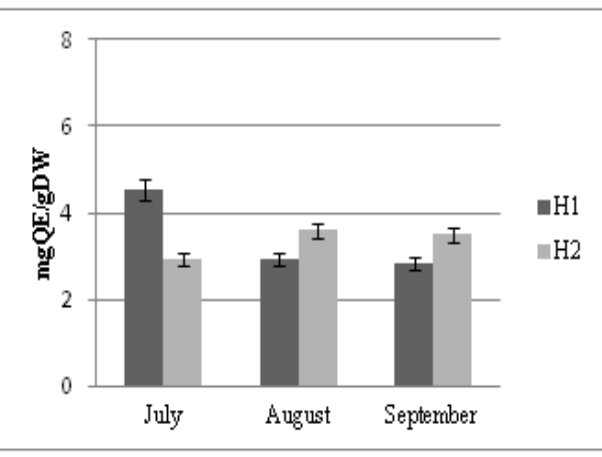

b)

Figure 2.a) Dynamics of total flavonoid content in $80 \%$ methanolic hydroalcoholic extract of the wild-growing $H$. perforatum $\mathrm{L}$. herba from the locality of H1 (Ljubišnja) i H2 (Vijenac).b) Dynamics of total flavonoid content in $50 \%$ ethanolic hydroalcoholic extract of the wild-growing $H$. perforatum L. herbae from the locality of H1 (Ljubišnja) i H2 (Vijenac).

The TPC and TFC values were found to be highly variable in quantity and their dynamics was found irregular unlike in Kazlauskas and Bagdonaite (2004) and Couceiro et al., (2006). We also take into consideration data obtained by Toker, (2009) and Ciraki, et al. (2013) for Hypericum triquetrifolium Turra species, which is known for its higher content of hypericin when compared with H. perforatum L. (Al-Snafi, 2018). The research of Toker, (2009) encompassed three (vegetative, full flowering and mature fruiting stage) and of Ciraki,et al. (2013) five developmental stages (vegetative stage, floral budding stage, full flowering stage, fresh fruiting stage and mature fruiting stage) and both researchers concluded that a peak of bioactive substances concentration was in full flowering stage, which is not the case in this research.

During the monitoring of the content of TPC and TFC, in the dried leaf (folium) of wild-growing M. officinalis L. during three consecutive months (July, August, September) for 80\% methanolic and 50\% ethanolic extracts (Figure 3. and 4.), the maximum value of these bioactive substances was detected in the month of August during the flowering period (for $80 \%$ methanolic extract on the locality M1 TPC $=41,66 \mathrm{mgGAE} / \mathrm{gDW}$ and TFC $=11,07 \mathrm{mgQE} / \mathrm{gDW}$ (Figure 3.a and Figure 4.a) and for 50\% ethanolic extracts on the locality M1 TPC = $40.15 \mathrm{mgGAE} / \mathrm{gDW}$ and $\mathrm{TFC}=8,42 \mathrm{mgQE} / \mathrm{gDW}$ (Figure 3.b and Figure 4.b), while the lowest values were found in the month of September

This range fits the value from Moacă et al., (2018) who found that TPC in the $M$. officinalis L. leaves extract was $32.76 \mathrm{mg} \mathrm{GAE} / \mathrm{g}$ dry material, as well as Rehan et al., (2014). A higher TPC equal to $227.6 \mathrm{mg} \mathrm{GAE} / \mathrm{gDW}$ was calculated 
for the hydroalcoholic extract from M. officinalis L. leaves (Moradi, et al., 2016) while the TFC of $12.5 \pm 2.11 \mathrm{mg} / \mathrm{g}$ as reported by Moradi et al., (2016), was in accordance with present data.

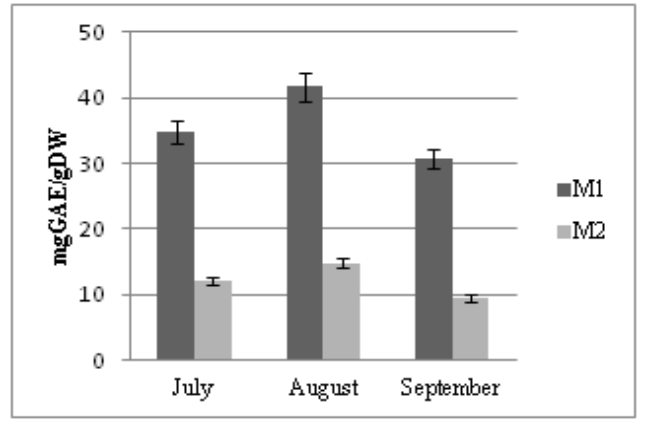

a)

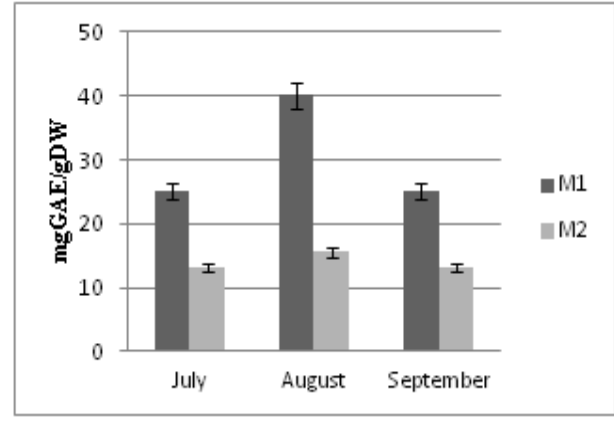

b)

Figure 3.a) Dynamics of total phenolic in $80 \%$ methanolic hydroalchoholic extract of dried wild-growing M. officinalis L. folium from the localities M1 (Zenica) and M2 (Stari Bar). b) Dynamics of total phenolic in 50\% ethanolic hydroalchoholic extract of dried wild-growing $M$. officinalis L. folium from the localities M1 (Zenica) and M2 (Stari Bar).

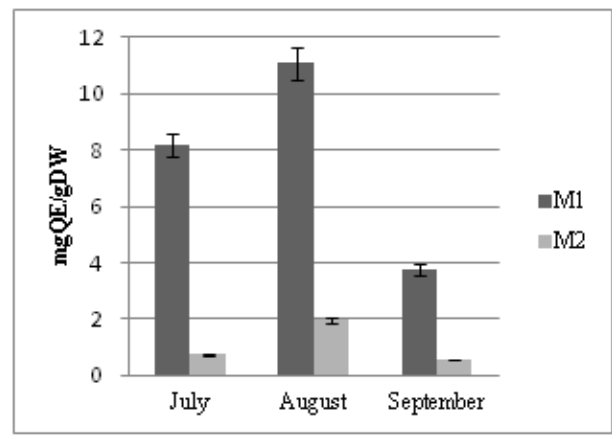

a)

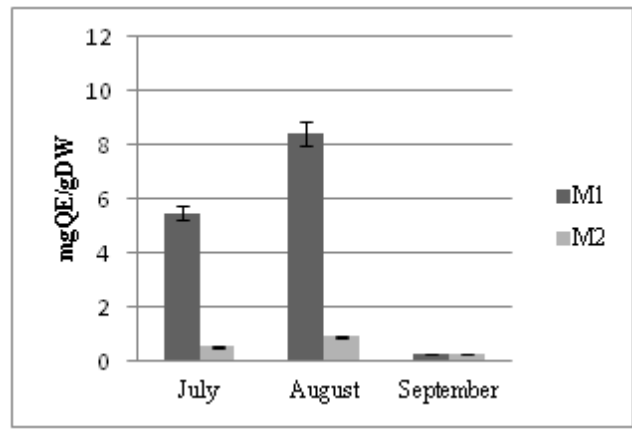

b)

Figure 4.a Dynamics of total flavonoids in $80 \%$ methanolic hydroalchoholic extract of dried wild-growing $M$. officinalis L. folium from the localities M1 (Zenica) and M2 (Stari Bar).b Dynamics of total flavonoids in 50\% ethanolic hydroalchoholic extract of dried wild-growing M. officinalis L. folium from the localities M1 (Zenica) and M2 (Stari Bar).

Total polyphenols in spray-dried extract before and after hydrodistillation was found the highest in M. officinalis L. among Lamiaceae family species, along with Origanum vulgare (Grigore et al. 2019).

For the M. officinalis L. species, the TPC and TFC were found to change in quantity in a regular manner during the plants vegetation cycle with the peak in 
the flowering stage (August), while the lowest concentration of these bioactive substances was found during fruiting stage (September), which is in a good agreement with the results of Saeb et al., (2011) who did the research on the plant material collected in India during three different plants development stages (vegetative growth, flowering stage and after flowering). Similarly, the amount of rosmarinic acid (\%) was studied in samples of $M$. officinalis L. leaves in dependence of the plant ontogenetic phase at harvest time (Tóth et al., 2003). Statistically non-significant variability of this phenolics acid was found. Nevertheless, maximum content was found in the full flowering stage $(3.91 \%)$ and minimum content in the stage just before flowering $(3.50 \%)$.

For the both of afore mentioned species, $80 \%$ methanolic extracts had higher concentrations of investigated bioactive substances than the $50 \%$ ethanolic extracts, which suggests $80 \%$ methanol being a better solvent for this purpose. The variation of TPC values according to the solvent used for the extraction is also described in the literature (Moacă et al., 2018). We should also take into account that content of bioactive substances in plants is changed according to climate, environmental conditions, different habitat and locality (Stefanović, et al., 2018). For instance, the methanolic extract gained from the aerial parts of $M$. officinalis L. wild-growing in Romania had a TPC of $22 \mathrm{mg} \mathrm{GAE} / \mathrm{g}$ extract (Armatu et al., 2010) and those from Bulgaria (herbae) a TPC of $48.86 \mathrm{mg} \mathrm{GAE} / 100 \mathrm{~g}$ dry weight (Atanassova et al., 2011). These findings reinforce present results on TPC in $M$. officinalis L. leaf extracts which highly differs depending on a habitat, especially altitude of the selected localities, for example TPC values for the M1 locality (846m) (August) was 41.66 mgGAE/gDW while for the M2 locality (178m) was (August) 14.77 mgGAE/gDW.

\section{CONCLUSIONS}

In this study variation of TPC and TFC during three consecutive months of vegetation cycle was presented for the two wild-growing plant species: $H$. perforatum $\mathrm{L}$. and $M$. officinalis $\mathrm{L}$. The results of this investigation point towards the recommendation of collecting plant material of $M$. officinalis L. in Montenegro during the flowering phase (month of August) in which there is the peak of TPC and TFC, which is not the case with $H$. perforatum $\mathrm{L}$.

\section{REFERENCES}

Albayrak, S., Aksoy, A., Sagdic, O. \& Hamzaoglu, E. (2010): Compositions, antioxidant and antimicrobial activities of Helichrysum (Asteraceae) species collected from Turkey. Food Chem, 119(1), 114-122.

Al-Snafi, A. E. (2018): Chemical constituents and pharmacological effects of Hypericum triquetrifolium. IAJPS, 05(03), 1757-1765.

Armatu, A., Colceru-Mihul, S., Bubueanu, C., Draghici, E. \& Pirvu, L. (2010): Evaluation of antioxidant and free scavenging potential of some Lamiaceae species growing in Romania. Romanian Biotech Lett, 15(3), 5274-5280. 
Artini, M., Patsilinakos, A., Papa, R., Božović, M., Sabatino, M., Garzoli, S., Vrenna, G., Tilotta, M., Pepi, F. \& Ragmo, R. (2018): Antimicrobial and antibiofilm activity and machine learning classification analysis of essential oils from different Mediterranean plants against Pseudomonas aeruginosa. Molecules, 23(2), 482.

Atanassova, M., Georgieva, S. \& Ivancheva, K. (2011): Total phenolic and total flavonoid contents, antioxidant capacity and biological contaminants in medicinal herbs. $J$. Univ. Chem. Technol. Metallurgy, 46(1), 81-88.

Benayad, Z., Martinez-Villaluenga, C., Frias, J., Gomez-Cordoves, C. \& Es-Safi, N. E. (2014): Phenolic composition, antioxidant and anti-inflammatory activities of extracts from Moroccan Opuntia ficus-indica flowers obtained by different extraction methods. Ind Crop Prod, 62, 412-420.

Boskovic, I., Đukić, D.A., Maskovic, P., Mandić, L. \& Perovic, S. (2018): Phytochemical composition and antimicrobial, antioxidant and cytotoxic activities of Anchusa officinalis L. extracts. Biologia, 73(11): 1035-1041.

Božin, B., Kladar, N., Grujić, N., Anačkov, A., Samojlik, I., Gavarić, N. \& Čonić, B. S. (2013): Impact of origin and biological source on chemical composition, anticholinesterase and antioxidant properties of some St. John's wort species (Hypericum spp., Hypericaceae) from the Central Balkans. Molecules, 18(10), 11733-11750.

Božović, M., Pirolli, A., \& Ragno, R. (2015): Mentha suaveolens Ehrh. (Lamiaceae) essential oil and its main constituent piperitenone oxide: biological activities and chemistry. Molecules, 20(5), 8605-8633.

Ciraki, C., Radusiene, J., Karpaviciene, B., Camasi, N., \& Odabas, M.S. (2013): Changes in phenolic content of wild and greenhouse grown Hypericum triquetrifolium during plant development. Turk J Agri, 37, 307-314

Couceiro, M.A., Afreen, F., Zobayed, S.M.A. \& Kozai, T. (2006): Variation in concentrations of major bioactive compounds of St. John's wort: effects of harvesting time, temperature and germplasm. Plant Sci, 170, 128-134.

Damjanović-Vratnica, B., Caković,. D. \& Perović, S. (2015): Composition and antimicrobial studies of essential oil of Thymus vulgaris from Montenegro. Biol. Nyssana, 6(2), 67-73.

Damjanović-Vratnica, B., Perović, A., Šuković, D. \& Perović, S. (2011): Effect of vegetation cycle on chemical content and antibacterial activity of Satureja montana L. Arch Bio Sci, 63(4), 1173-1179.

Dixon, R.A. (2001): Natural products and plant disease resistance. Nature, 411(6839), 843-847.

Fialová, S., Tekelova, D., Mrlianova, M. \& Grančai, D. (2008): The determination of phenolics compounds and antioxidant activity of mints and balms cultivated in Slovakia. Acta Fac Pharm Univ Comen, 55, 96-102.

Germ, M., Stibilj, V., Kreft, S., Gaberščik, A. \& Kreft, I. (2010): Flavonoid, tannin and hypericin concentrations in the leaves of St. John's wort (Hypericum perforatum L.) are affected by UV-B radiation levels. Food Chem, 122(3), 471-474.

Grigore, A., Bubueanu, C., Pirvu, L., Nita, S., Cristina, B. \& Dobre, N. (2019): Polyphenol content dynamics in hydrodistillation water residues of Lamiaceae species. J Essent Oil Bear Pl, 22(3), 858-864.

Habila, J. D., Bello, I. A., Dzikwi, A. A., Musa, H. \& Abubakar, N. (2010): Total phenolics and antioxidant activity of Tridax procumbens Linn. Afr J Phar Pharmaco, 4(3), 123-126. 
Halliwell, B. (2006): Reactive species and antioxidants. Redox biology is a fundamental theme of aerobic life. Plant Physio, 141, 312-322

Kazlauskas, S. \& Bagdonaite, E. (2004): Quantitative analysis of active substances in St. John's wort (Hypericum perforatum L.) by the high-performance liquid chromatography method. Medicina (Kaunas, Lithuania), 40(10): 975-81.

Mártonfi, P., Repčák, M. \& Mártonfiová, L. (2006): Secondary metabolites during ontogenetic phase of reproductive structures in Hypericum maculatum. Biologia, 61, 473-478.

Moacă, E. A., Farcaş, C., Ghiţu, A., Coricovac, D., Popovici, R., Cărăba-Meiţă, N.L., Ardelean, F., Antal, D. S., Dehelean, C. \& Avram, S. (2018): A comparative study of Melissa officinalis leaves and stems ethanolic extracts in terms of antioxidant, cytotoxic, and antiproliferative potential. Evid-Based Compl Alt, 12 pages.

Moradi, M.T., Karimi, A., Alidadi, S. \& Hashemi, L. (2016): In vitro anti-adenovirus activity, antioxidant potential and total phenolic compounds of Melissa officinalis L. (lemon balm) extract. Int. J. Pharmacogn. Phytochem. Res, 8(9), 1471-1477.

Nahrstedt, A. \& Butterweck, V. (2010): Lessons learned from herbal medicinal products: the example of St. John's Wort. J Nat Prod, 73(5), 1015-1021.

Obložinský, M., Bezáková, L., Holková, I., Vanko, M., Kartnig, T. \& Pšenák, M. (2006): Antilipoxygenase activity of compounds from Hypericum perforatum. Biologia, 61, 331-332.

Olech, M., Nowak, R., Loś, R., Rzymowska, J., Malm, A. \& Chrusciel, K., (2012): Biological activity and composition of teas and tinctures prepared from Rosa rugosa Thunb. Open Life Sci, 7, 172-182.

Rehan, T., Tahira, R., Rehan, T., Bibi, A. \& Naeemullah, M. (2014): Screening of seven medicinal plants of family Lamiaceae for total phenolics, flavonoids and antioxidant activity. Pakhtunkhwa J Life Sci, 02(03/04), 107-117.

Saeb, K., Gholomreazee, S. \& Asadi, M. (2011): Variation of antioxidant activity of Melissa officinalis leaves extracts during the different stages of plant growth. Biomed Pharmaco J, 4(2), 237-243.

Sarbu, L. G., Bahrin, L.G., Babii, C., Stefan, M. \& Birsa, M. L. (2019): Synthetic flavonoids with antimicrobial activity: A review. J Appl Microbiol, 127, 12821290.

Sarikurkcu, C., Locatelli, M., Tartaglia, A., Ferrone, V., Juszczak, M., A., Ozer, S. M., Tepe, B. \& Tomczyk, M. (2020): Enzyme and Biological Activities of the Water Extracts from the Plants Aesculus hippocastanum, Olea europaea and Hypericum perforatum That Are Used as Folk Remedies in Turkey. Molecules, 25(5): 1202.

Šćepanović, A., Krivokapić, S., Šćepanovic, V., Živković, V. \& Perović, S. (2019): Chemical constituents and biological potential of essential oils of Helichrysum italicum (Roth) G. Don from Montenegro. Agriculture \& Forestry, 65(2), 53-58.

Škrovánková, S., Mišurcová, L. \& Machů, L. (2012): Antioxidant activity and protecting health effects of common medicinal plants. Adv Food Nutr Res, 67, 75-139.

Sofowora, A., Ogunbodede, E. \& Onayade, A. (2013): The role and place of medicinal plants in the strategies for disease prevention. Afr J Tradit Complem, 10(5), 210229.

Stefanović, O., Ličina, B., Vasić, S., Radojević, I. \& Čomić, L. (2018): Bioactive extracts of Gentiana asclepiadea: antioxidant, antimicrobial, and antibiofilm activity. Botanica Serbica, 42(2), 223-229. 
Stešević, D., Božović, M., Tadić, V., Rančić, D. \& Stevanović, Z. D. (2016): Plant-part anatomy related composition of essential oils and phenolic compounds in Chaerophyllum coloratum, a Balkan endemic species. Flora, 220, 37-51.

Sujana, P., Sridhar, T. M., Josthna, P. \& Naidu, C. V. (2013): Antibacterial activity and phytochemical analysis of Mentha piperita L. (Peppermint)-An important multipurpose medicinal plant. Am J Plant Sci, 4, 77-83.

Tadić, V., Oliva, A., Božović, M., Cipolla, C., De Angelis, M., Vullo, V., Garzoli, S. \& Ragno, R. (2017): Chemical and antimicrobial analyses of Sideritis romana L. subsp. purpurea (Tal. ex Benth.) Heywood, an endemic of the Western Balkan. Molecules, 22(9), 1395.

Tausevski, O., Krstikj M., Petreska Stanoeva, J. \& Stefova, M. (2019): Phenolic Compounds Composition of Hypericum perforatum L. Wild-Growing Plants from the Republic of Macedonia. Agric Conspec Sci, 84(1): 67-75.

Toker, Z. (2009): Variation of total hypericin, phenolic and flavonoid compounds in Hypericum triquetrifolium during its phenological cycle. Pharma Bio, 47(4), 285288.

Tóth, J., Mrlianová, M., Tekel’ová, D. \& Koreňová, M. (2003): Rosmarinic acid - Am important phenolic active compound of Lemon balm (Melissa officinalis L.). Acta Fac Pharm Uni Comen, 50, 139-146.

Vuković-Gačić, B., Nikčević, S., Berić-Bjedov, T., Knežević-Vukčević, J. \& Simić, D., (2006): Antimutagenic effect of essential oil of sage (Salvia officinalis L.) and its monoterpenes against UV-induced mutations in Escherichia coli and Saccharomyces cerevisiae. Food Chem Toxicol, 44(10), 1730-1738.

Zobayed, S.M.A., Afreen, F., Goto, E. \& Kozai, T. (2006): Plant-environment interactions: accumulation of hypericin in dark glands of Hypericum perforatum. Ann Bot, 98(4), 793-804.

Zou, Y., Lu, Y. \& Wei, D. (2004): Antioxidant activity of a flavonoid-rich extract of Hypericum perforatum L. in vitro. J Agri Food Chem, 52, 5032-5039. 